
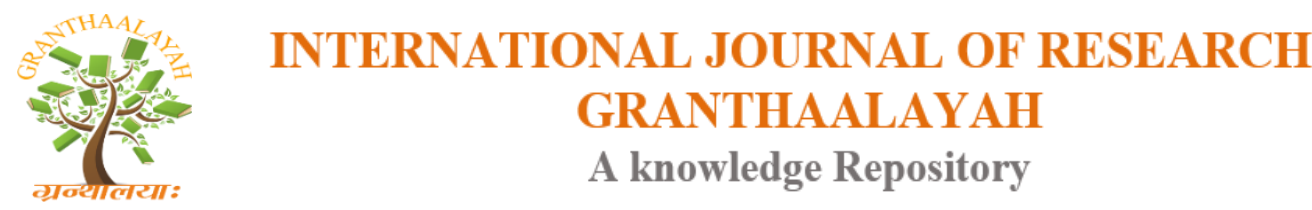

Management

\title{
SPATIAL PATTERN OF HOUSEHOLD TRAVEL IN MINNA METROPOLIS, NIGERIA
}

\author{
Ojekunle Joel Ademola (Ph.D) ${ }^{* 1}$, Owoeye Adelanke Samuel ${ }^{1}$ \\ ${ }^{1}$ Department of Transport Management Technology, School of Entrepreneurship and \\ Management Technology, Federal University of Technology, Minna, Nigeria
}

\begin{abstract}
Household travel is the major origin of traffic flow in the urban centres. Urban residents travel for various purposes; planning and managing urban travel requires that city planners and managers understand their flow pattern across the city space. This study therefore, was conducted to analyse the spatial pattern of household travel in Minna City, Nigeria. The data were collected through questionnaire administration on 1,303 respondents using Open Data Kit (ODK) package. To do this, the city was divided into four cluster zones, from which three different residential densities were selected in each of the zones. The study reveals that trip generation and attraction is significantly different among different residential densities in the city. The analysis of variance reveals there is significant difference in trip distances covered by different residential area in the city with a p-value of $<0.001$. The study therefore recommends that there is need to create spatial balance in the location of services needed and land use activities across the residential densities and also provide an effective and efficient public transportation system to the city residents especially along the main traffic corridors.
\end{abstract}

Keywords: Household Trips; Travel; Residential Densities; City Neighbourhood and Spatial Pattern.

Cite This Article: Ojekunle Joel Ademola, and Owoeye Adelanke Samuel. (2018). "SPATIAL PATTERN OF HOUSEHOLD TRAVEL IN MINNA METROPOLIS, NIGERIA.” International Journal of Research - Granthaalayah, 6(5), 276-288. 10.29121/granthaalayah.v6.i5.2018.1449.

\section{Introduction}

The necessity for people to move from one place to another in urban centres is dictated by the spatial spread of activities within the urban environment (Fadare and Salami, 2004). Human activities must take place in an environment which also attracts mobility to the land use within the city center or the hinterland. Activities like working, shopping, religious worship, recreation and others necessitate the movement of people or household from one neighbourhood to another. The importance of transportation in this regard cannot be over-emphasized. Transportation for instance centrally affects the relationship between physical space and society, and changes in transportation affect the organization of human activity in urban and regional space. It structures the built 
environment, spurs urban growth, as well as orders relationships among cities in a national urban system (Yago, 1983).

The environment in which transport analysis and infrastructure planning is taking place has transformed drastically during last few decades. Hence, due to urbanization in developing countries, the big cities are experiencing sustained strain due to heavy migration from rural areas to different residential densities in the urban centres (Subbarao and Krishna, 2013). Intra-urban trip represents an expression of an individual's behavior and such it has the characteristics of being habitual, it tends to be repetitive and the repetition occurs in explicit pattern (Solanke, 2014). The complexity of urban travel is a major challenge for transport planners and urban managers in major cities of the world where people from different socio-economic background travel for different purposes at different time of the day within the residential neighbourhoods.

Spatial interaction theory provides a basis for the understanding and analysis of transport flows in urban area. Transport flows involve the movement of commuters, goods and services between places. It varies in direction, scale, speed, capacity and content depending on the methods of transport used (Okoko, 2008). Spatial interaction therefore includes such activities as traffic, travel and communications. The spatial patterns of interactions have found to be varied from one location of the city to another. The spatial pattern of urban travels dictates the supply and location of transport facilities. The spatial differences in the volume and scale of urban travels have been attributed to a number of factors which include the spatial distribution of land uses, the socioeconomic characteristics of urban residents, the population and population density of urban centres as well as density of residential landuse (Ojekunle 2016). This calls for the need to constantly investigate the parameters that play key roles in this dynamism of travel behaviour.

The search for explanation on the spatial pattern of urban travel in developing countries particularly in Nigeria is not a conclusive one. More research has to be done to establish various patterns of urban trip generation and how different land uses affect these patterns. It is against this backdrop, that this study attempts to analyze the spatial pattern of household travel in Minna Metropolis, Niger State, Nigeria. No wonder Clifton and Handy (2001) asserted that the more we understand about urban travel behaviour, the more we recognize how much we do not understand, because, as one question is answered, new questions emerge, and our appreciation of the complexity of travel behaviour grows. This study therefore laid emphasis in examining the differences in trip making pattern of households in the residential densities of Minna.

\section{Literature Review}

Trip pattern studies within the urban centres have long attracted the attention of researchers in the field of travel behaviour. Since the early 1970's researchers have changed their focus away from the traditional studies of purpose and mode of intra-urban travel to those that can effectively capture the developments fundamental to travel patterns in the light of the existing technology and current planning procedures. Consequently, studies since this period have been concerned with illuminating how and why individuals distribute their trips from one or more given origin points.

The early work of Kansky (1967), Harton and Hultiquists (1971) on travel behaviour used multiple measures of travel pattern though none of these systematically related the travel pattern to personal 
attributes of travellers in the residential densities. Many studies in Europe and North America have established that residential density or location positively affects individuals and household travel behavior (Hanson and Hanson, 1981). Fadare and Hay (1990) observed that trip mode and trip length and their determinants varied significantly across the three housing density areas of Ibadan in Nigeria.

Ayeni (1979) argued that an examination of movement patterns in a city should follow at least two approaches. The first approach involves an examination of some determinants of trips at the household, firm or individual levels while the second approach is focused on the capacity of the various land use to generate and attract trips. Fadare and Hay (1990) noted that various trips exist in the socio-economic attributes of urban residents as a result of the density of their residential areas which has implications for their trip generation. It was observed that urban form plays a significant part in influencing travel patterns and behaviours in low density and single use land zoning which produces longer travel journeys which results to a greater reliance on the use of the car as the principal means of transport (Boarnet and Crane, 2001).

\section{The Study Area}

Minna is a fast developing urban centre in North-Central Nigeria. It is located between Latitudes $8^{\circ} 20^{\prime} \mathrm{N}$ and $11^{\circ} 30^{\prime} \mathrm{N}$ and between Longitude $3^{\circ} 30^{\prime} \mathrm{E}$ and $7^{\circ} 20^{\prime} \mathrm{N}$, and lies wholly with the physical and cultural zone of transition described as the "middle belt of Nigeria". Kaduna and Federal Capital Territory border the State to both North-East and South-West respectively. Minna has a total land area of $74,344 \mathrm{~km}^{2}$ wide and it is approximately $8 \%$ of the land area of the country. Three homogenous residential densities of low, medium and high were recognised in Minna. These residential areas are characterized by social, economic and physical patterns. The city of Minna is the administrative Capital of Niger State in Nigeria with a estimated population 286,838 as at 2016. Figure 1 shows map of Nigeria and the location of Niger State is indicated in blue colour. Also, Figure 2 shows the map of Niger State and the location of Minna within the state, while Figure 3 shows the map of Minna City with its various residential land uses.

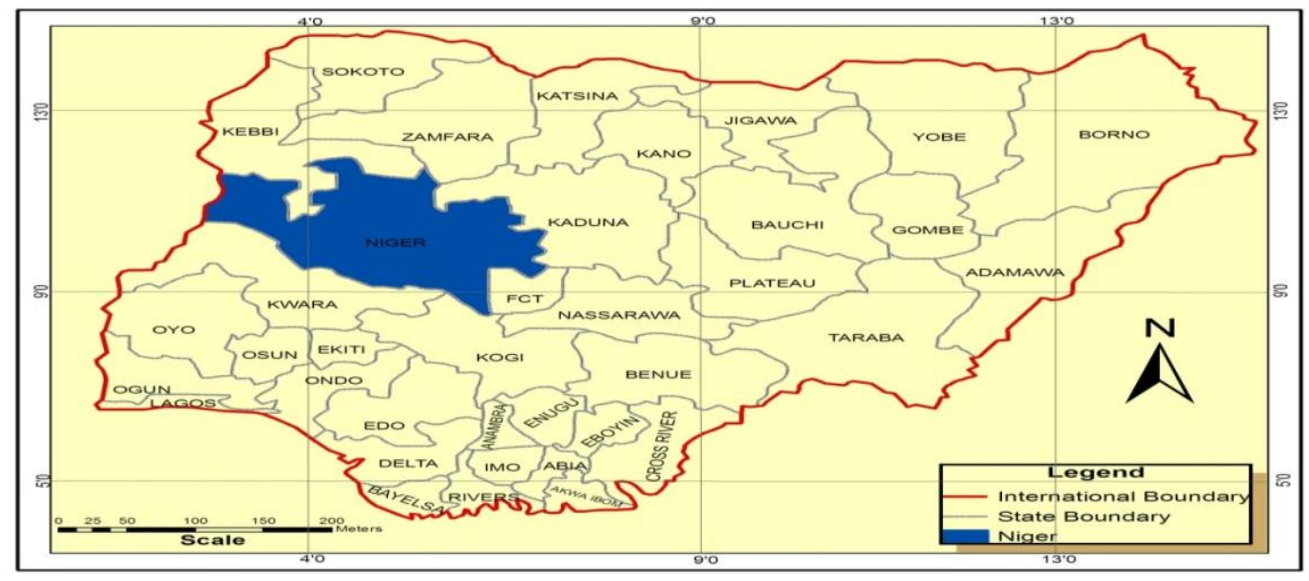

Figure 1: Map of Niger State in the context of Nigeria

Source: Niger State Ministry of Lands and Housing (2018) 


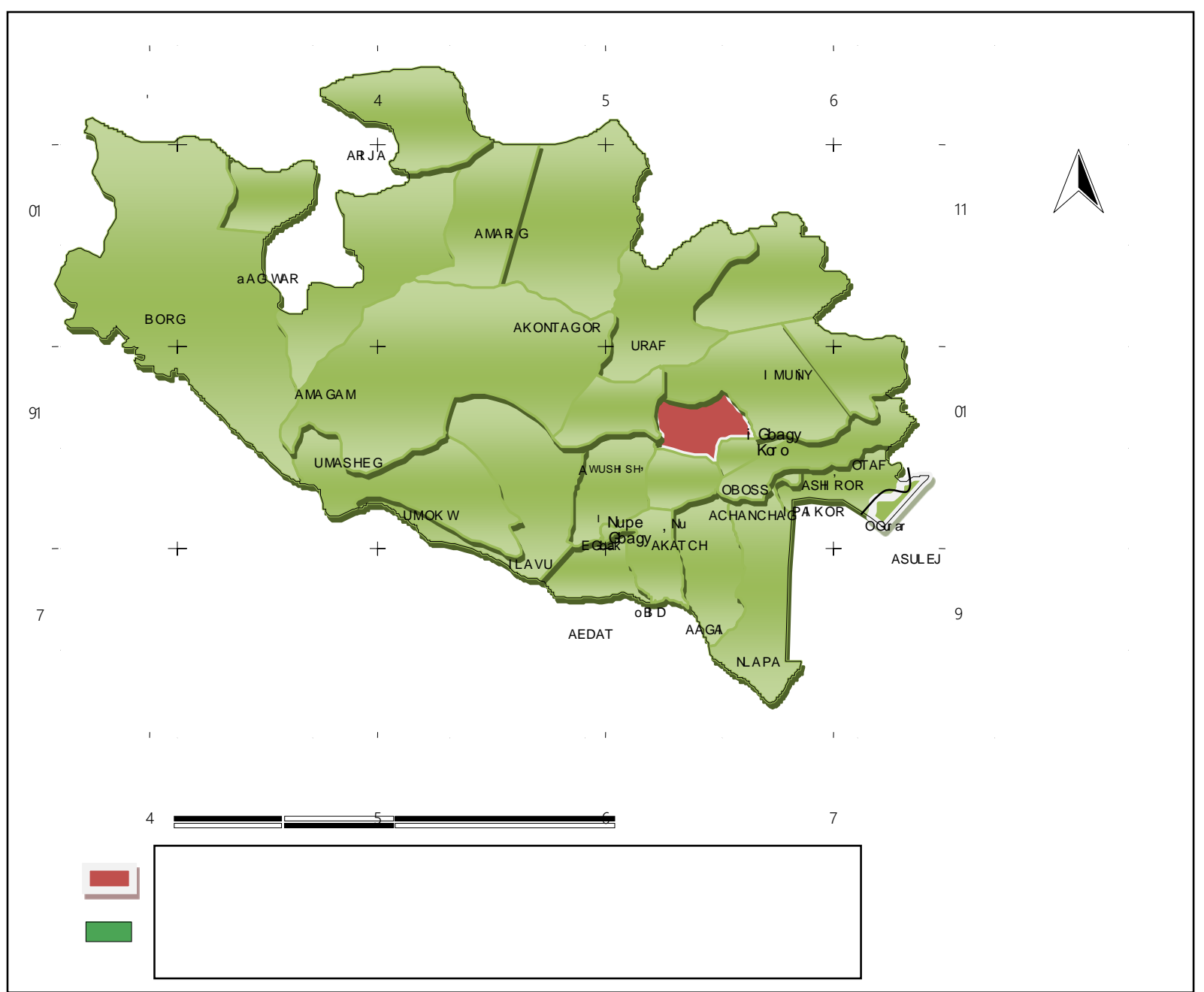

Figure 2: Map of Minna in the context of Niger State

\section{Source: Niger State Ministry of Urban and Housing Development (2016)}

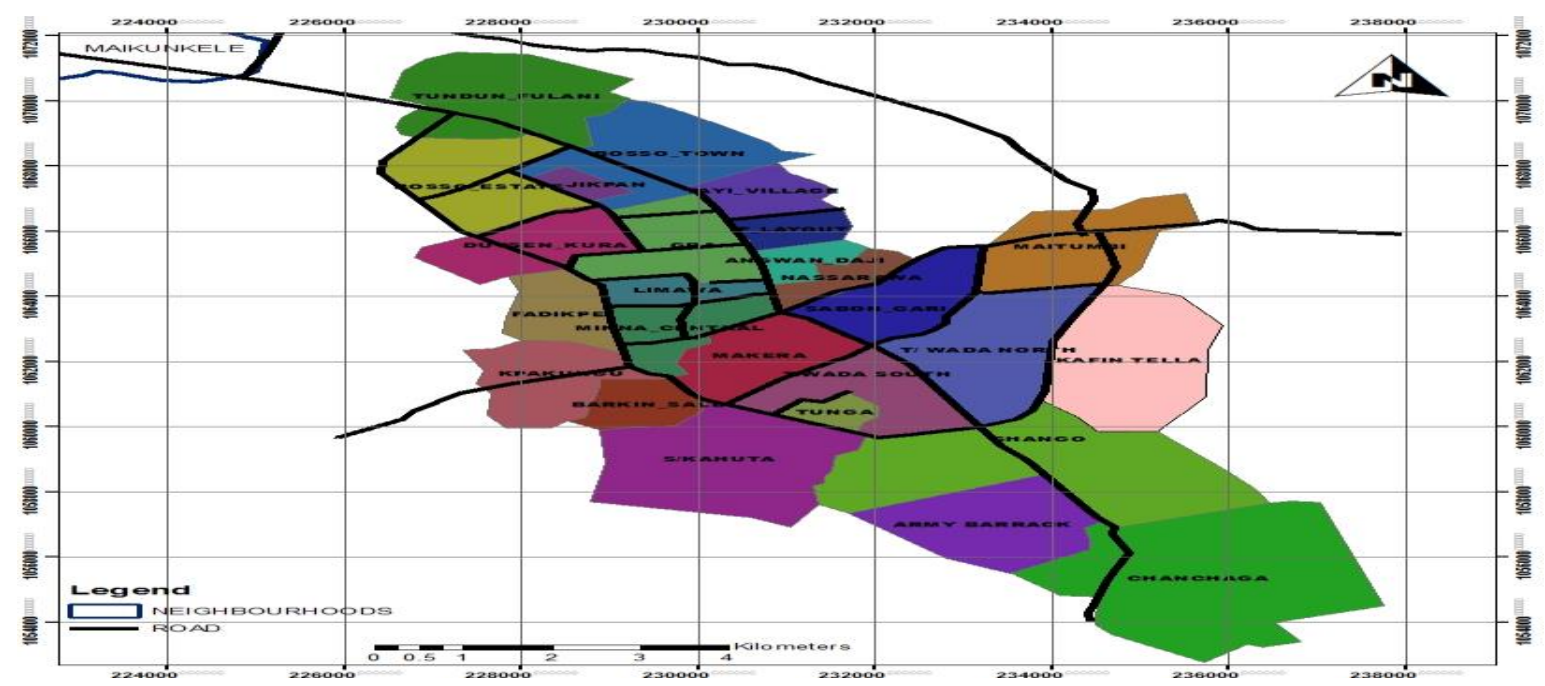

Figure 3: Neighbourhoods Structures in Minna

Source: Author's Field work (2018) 


\section{Materials and Methods}

A cross-sectional survey approach was used to examine the spatial pattern of trip making of household in the city. A multistage sampling technique was adopted for this study. The study area was divided into four clusters using the major traffic corridors as boundaries. In each cluster, three neighbourhoods of low, medium and high densities were selected.

To determine the appropriate sample size, the current population of the city was obtained from National Population Commission (NPC). From the NPC's record, the town has a current estimated population of 176,753. Since the household is the target population, according to Nigerian Bureau of Statistics (NBS, 2010), an average number of 6 persons live in a household. The population is therefore divided by 6 which gave rise to 29,459 households. However, this population size is considered too much, a Dillman (2007) formula was adopted for determining the appropriate sample size. Based on this a total number of 1,303 sample size was arrived at. Questionnaires were administered on this population using Open Data Kit (ODK) at 12 residential locations in the city. The locations were choosing based on the characteristics and densities of residential land uses. Figure 4 shows the map of the Study Area and the four cluster areas in which the City is divided. The locations shown in green colour are the selected residential areas for the data collection.

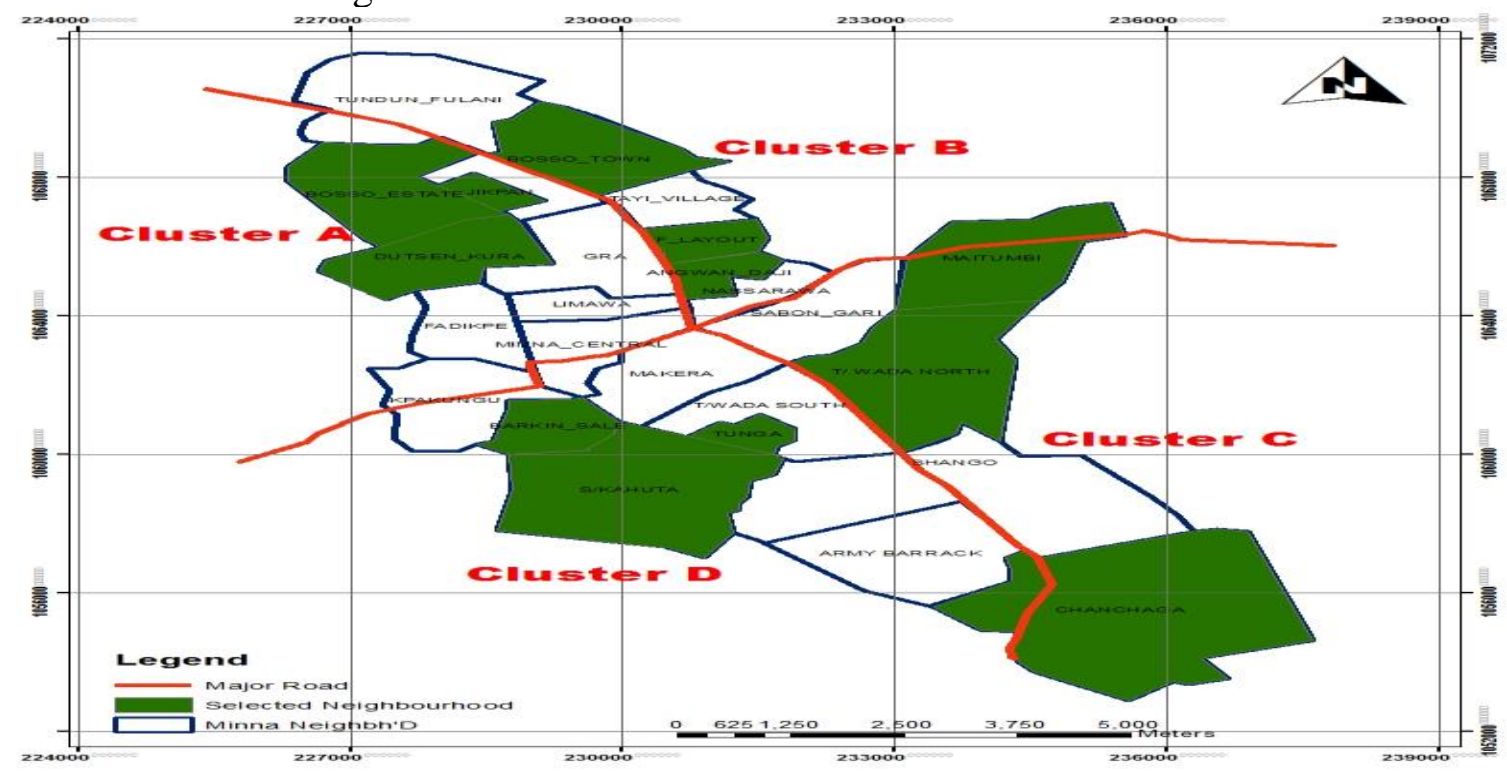

Figure 4: Selected 12 Neighbourhoods in Minna

\section{Source: Author's field work (2017)}

In each neighbourhood, systematic random sampling method was adopted for questionnaire distribution on household heads based on the population of the neighbourhoods. In cluster A; Bosso Estate, Dutsen Kura and Jikpan were neighbourhood selected, while in Cluster B; Bosso Town, F-Layout and Angwan Daji were selected. In cluster C; Maitumbi, Tudun Wada North and Chanchaga were the selected neighbourhood while, Barkin Saleh, Tunga and Saka Kahuta were selected in cluster D. Out of 1,303 questionnaires administered, only 888 were correctly administered and returned for analysis. For data analysis, GIS software applications were deployed to show different patterns of household travels in Minna metropolis

Table 1: Sample Size and Questionnaires Returned for the Selected Neighbourhoods 


\begin{tabular}{|c|c|c|c|c|c|c|}
\hline $\begin{array}{l}\text { Clust } \\
\text { er }\end{array}$ & $\begin{array}{l}\text { Neighbourho } \\
\text { ods }\end{array}$ & $\begin{array}{l}2006 \text { Census } \\
\text { Results }\end{array}$ & $\begin{array}{l}2006 \text { - } \\
2016 \\
\text { Projecte }\end{array}$ & $\begin{array}{l}\text { Number of } \\
\text { Households } \\
\text { in each } \\
\text { Neighbourh }\end{array}$ & $\begin{array}{l}\text { Househol } \\
\text { ds } \\
\text { Sample }\end{array}$ & $\begin{array}{l}\text { Households } \\
\text { Questionnai } \\
\text { res }\end{array}$ \\
\hline $\mathbf{A}$ & Bosso Estate & 583 & 799 & 133 & 05 & 05 \\
\hline $\mathbf{A}$ & Dutsen Kura & 6,604 & 9,049 & 1,508 & 67 & 48 \\
\hline $\mathbf{A}$ & Jikpan & 6,604 & 9,049 & 1,508 & 67 & 50 \\
\hline B & Bosso Town & 43,856 & 60,091 & 10,015 & 443 & 278 \\
\hline $\mathrm{B}$ & F-Layout & 6,604 & 9,049 & 1,508 & 67 & 52 \\
\hline B & Angwan Daji & 612 & 839 & 140 & 6 & 6 \\
\hline $\mathbf{C}$ & Maitumbi & 17,775 & 24,355 & 4,059 & 180 & 125 \\
\hline $\mathrm{C}$ & $\begin{array}{l}\text { Tudun-Wada } \\
\text { North }\end{array}$ & 6,494 & 8,898 & 1,483 & 66 & 50 \\
\hline $\mathbf{C}$ & Chanchaga & 23,236 & 31,838 & 5,306 & 235 & 148 \\
\hline D & Barkin Sale & 5,862 & 8,032 & 1,339 & 58 & 44 \\
\hline D & Tunga & 6,494 & 8,898 & 1,483 & 66 & 46 \\
\hline \multirow[t]{2}{*}{ D } & Sauka Kahuta & 4,274 & 5,856 & 976 & 43 & 36 \\
\hline & Total & 128,998 & 176,753 & 29,459 & 1,303 & 888 \\
\hline
\end{tabular}

Source NPC (2006); Author's Projection and Compilation (2016)

\section{Results and Discussions}

\subsection{Origin and Destination Analysis of Household Trips}

One of the important features of urban trip generation is the origin and destination of urban travellers. Every trip originates from a particular geographical location and terminates in another location. Urban trips mostly originate from residential locations and terminate at non-residential locations where desires of travellers are fulfilled. In this study, we try to examine how trips are generated and attracted in Minna. The results of the finding are presented in Table 2 below. From the table, Bosso Residential Area of the City generates the highest trips, it records 4451 trips weekly. The second highest is generated by Chanchaga Area which records 1550 weekly trips. The least weekly trip was recorded by Agwa Daji with 142 trips. In terms of trip attraction, the highest trip was attracted by the Minna Central Area with a weekly trip of 3055. The next major attracting zone in the City is Bosso Area with a weekly trip of 2068. The next in this order trip attraction is Chanchaga Area which records 873 weekly trips.

This finding implies that the City Central Area is the major centre of trip attraction while Bosso is the major trip generation area of the City. There is high level of interactions between Bosso and Central Area. Not only, the table further reveals that Bosso is both a trip generating and attracting zone just like Chanchaga. The major factor that is responsible for this trip pattern is the types and intensity of land use activities found in these locations.

Table 2: Origin-Destination Matrix of Weekly Household Trips in Minna 


\begin{tabular}{|c|c|c|c|c|c|c|c|c|c|c|c|c|c|c|c|c|c|c|c|c|c|c|c|c|c|}
\hline 总 & 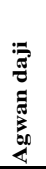 & 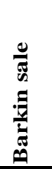 & 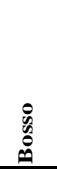 & 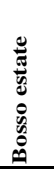 & 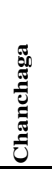 & 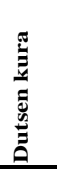 & 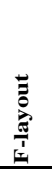 & 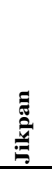 & 完 & 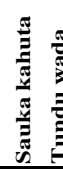 & 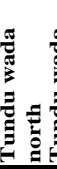 & 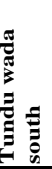 & $\underset{E}{\stackrel{g}{g}}$ & 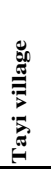 & 苞 & 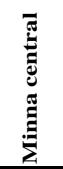 & 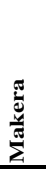 & 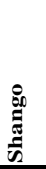 & $\begin{array}{l}\bar{\pi} \\
\bar{y} \\
\tilde{y} \\
\tilde{z} \\
\tilde{z}\end{array}$ & 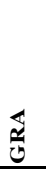 & 节 & 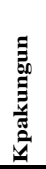 & 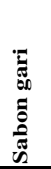 & 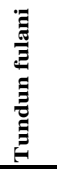 & 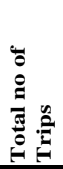 \\
\hline$\overline{\text { Agwan daji }}$ & 15 & 5 & 15 & 1 & 5 & 11 & 5 & 2 & $\overline{0}$ & 9 & 0 & $\overline{0}$ & 10 & 0 & $\overline{0}$ & 39 & 0 & 0 & $\overline{0}$ & $\overline{0}$ & $\overline{0}$ & 10 & 8 & 7 & 142 \\
\hline Barkin sale & 2 & 89 & 80 & 10 & 10 & 33 & 30 & 20 & 21 & 30 & 10 & 9 & 15 & 0 & 1 & 70 & 10 & 12 & 5 & 3 & 15 & 40 & 25 & 30 & 570 \\
\hline Bosso & 150 & 120 & 1200 & 63 & 300 & 229 & 30 & 50 & 10 & 30 & 10 & 480 & 100 & 4 & 4 & 1300 & 3 & 8 & 6 & 20 & 7 & 180 & 45 & 102 & 4451 \\
\hline Bosso estate & 26 & 5 & 49 & 10 & 25 & 29 & 9 & 4 & 3 & 2 & 1 & 1 & 8 & 0 & 0 & 40 & 2 & 10 & 3 & 5 & 5 & 20 & 12 & 11 & 280 \\
\hline Chanchaga & 8 & 18 & 158 & 19 & 394 & 12 & 16 & 12 & 10 & 15 & 31 & 23 & 80 & 0 & 23 & 510 & 41 & 36 & 4 & 15 & 8 & 32 & 60 & 25 & 1550 \\
\hline Dutsen kura & 19 & 21 & 45 & 14 & 38 & 242 & 9 & 6 & 4 & 7 & 0 & 0 & 50 & 0 & 4 & 135 & 6 & 18 & 16 & 20 & 19 & 45 & 12 & 24 & 754 \\
\hline F-layout & 8 & 16 & 62 & 30 & 10 & 134 & 90 & 2 & 16 & 13 & 0 & 0 & 10 & 4 & 0 & 207 & 0 & 3 & 0 & 2 & 33 & 9 & 1 & 3 & 653 \\
\hline Jikpan & 12 & 32 & 140 & 40 & 1 & 105 & 15 & 108 & 0 & 4 & 1 & 3 & 54 & 2 & 8 & 41 & 14 & 21 & 0 & 0 & 30 & 10 & 0 & 8 & 649 \\
\hline Maitumbi & 0 & 0 & 212 & 0 & 48 & 420 & 1 & 39 & 279 & 1 & 0 & 0 & 48 & 2 & 2 & 390 & 0 & 0 & 3 & 3 & 3 & 3 & 70 & 1 & 1525 \\
\hline Sauka kahuta & 4 & 14 & 38 & 8 & 8 & 77 & 18 & 6 & 4 & 30 & 4 & 8 & 20 & 3 & 9 & 85 & 7 & 6 & 5 & 2 & 6 & 16 & 11 & 9 & 398 \\
\hline $\begin{array}{l}\text { Tundu wada } \\
\text { north }\end{array}$ & 0 & 2 & 44 & 4 & 16 & 98 & 12 & 10 & 0 & 18 & 60 & 24 & 48 & 0 & 0 & 104 & 0 & 2 & 0 & 0 & 0 & 8 & 8 & 4 & 462 \\
\hline Tunga & 2 & 4 & 25 & 0 & 18 & 123 & 34 & 1 & 8 & 21 & 0 & 0 & 180 & 13 & 0 & 134 & 6 & 1 & 18 & 9 & 3 & 19 & 26 & 12 & 657 \\
\hline Total & & & & & & & & & & & & & & & & & & & & & & & & & \\
\hline Trips & 246 & 326 & 2068 & 199 & 873 & 1513 & 269 & 260 & 355 & 180 & 117 & 548 & 623 & 28 & 51 & 3055 & 89 & 117 & 60 & 79 & 129 & 392 & 278 & 236 & 12091 \\
\hline
\end{tabular}

\section{Source: Author's Field Work (2017)}

\subsection{Spatial Pattern of Household Trip Generation and Attraction}

Figure 2 reveals trip generation patterns of households in three residential densities of Cluster A; Jikpan, Dutsen Kura and Bosso Estate. There is high level of interaction between Jikpan and Bosso Town, Jikpan and Dutsen Kura, Bosso Estate and Agwan Daji, Dutsen Kura and Minna Central. This is because of the mixed land use of educational, residential and commercial activities prevalent among the three neighbourhoods. Volume of trips made between Dutsen Kura and Minna central Area is essentially high because Minna central is basically the hub of social economic activities and the commercial nerve of the city where shopping malls, bus parks, Market, etc are sited.

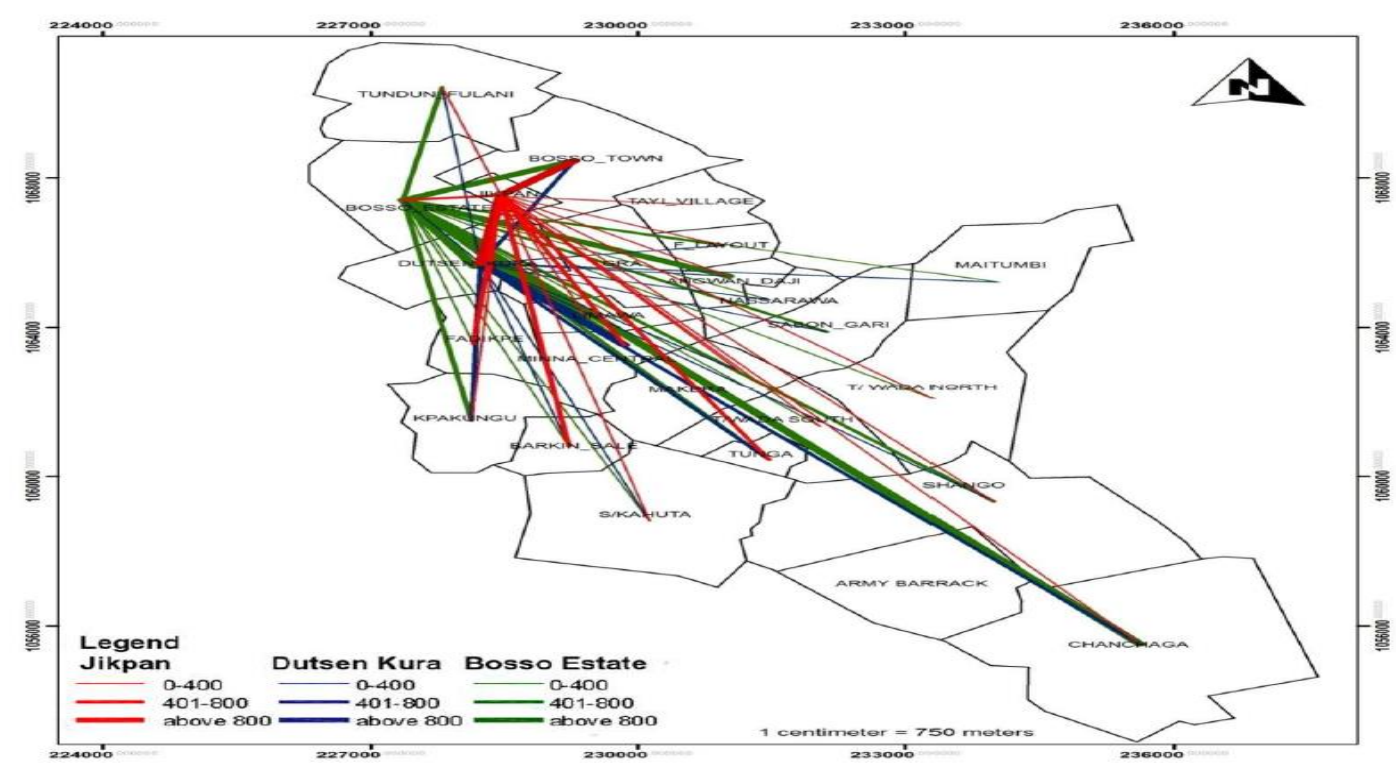

Figure 5: Zonal Trip Generation Patterns of Households in Cluster A

Source: Author's Computer Generation (2017) 
Figure 5 reveals high intensity of trips between Bosso Town and Minna Central, Agwan Daji and Minna Central and F-Layout and Minna Central. Reasons for this high volume of trips are because these areas function as residential, educational, commercial centres with concentration of economic and work related activities. Most residents go to work between these neighbourhoods. While, the farthest trips were made between Bosso Town and Chanchaga because residents goes there for work and education related activities due to the presence of banks, commercial centres and Niger State College of Education.

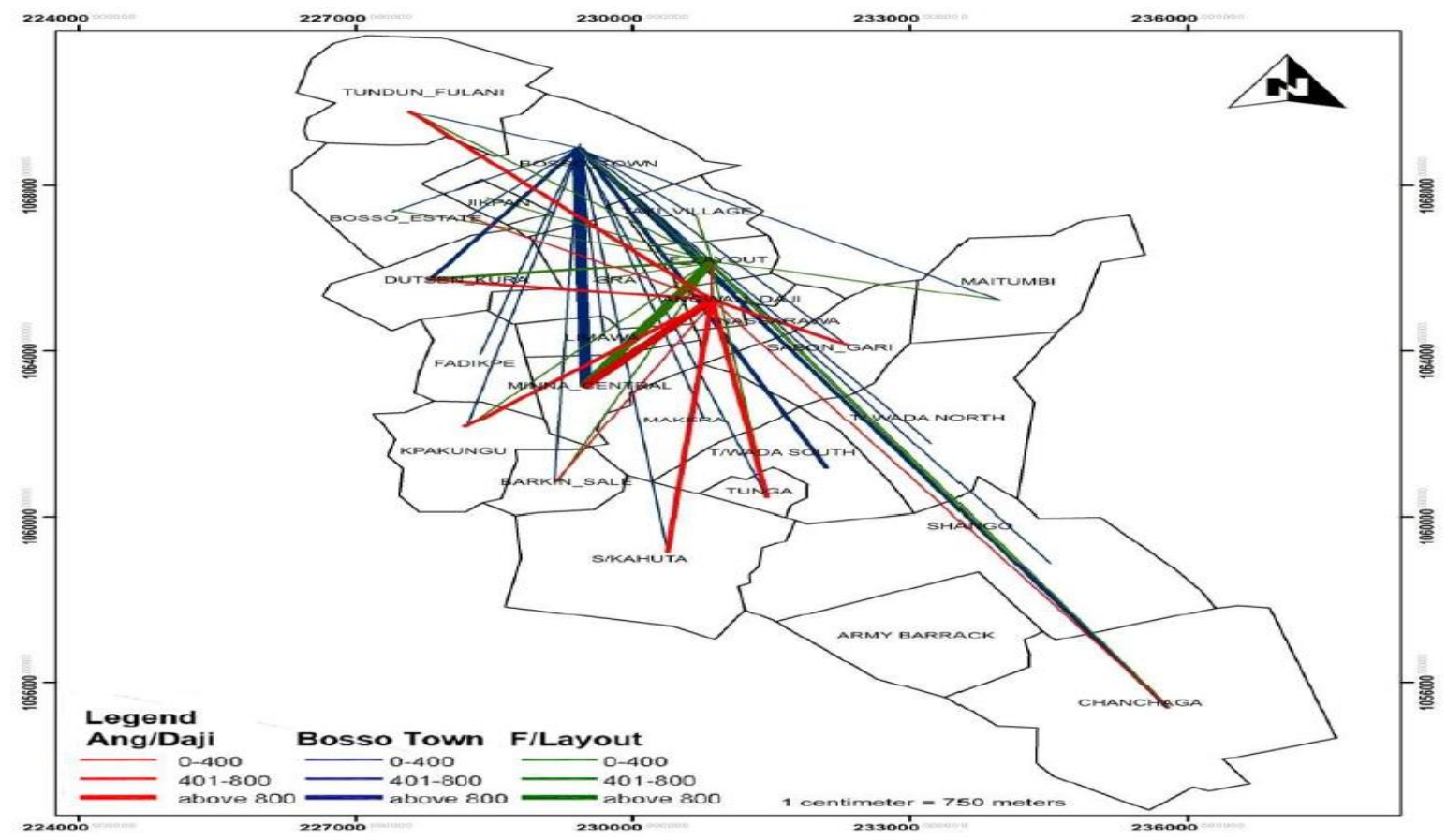

Figure 6: Zonal Trip Generation Patterns of Households in Cluster B Source: Author's Computer Generation (2017)

Figure 6 reveals high interaction between Maitumbi and Dutsen Kura because Dutsen Kura is the location of Kure Modern Market which the hub of trading activities in Minna. Hence, resident goes there to purchase goods and provide services in one way or another. Maitumbi and Minna Central also attract high volume of trips because Minna Central is the Central Business District (CBD) of the city where most business and economic activities takes place which is supported by adequate road connectivity and is accessible. This is also the hub of public transport services with parking lots and transport garages for commercial and public transportation.

Chanchaga, Tundu Wada North and Minna Central as well attract high volume of trips because Niger State College of Education and Niger State University of Education are sited in Chanchaga. Majority of the resident's live and work within these neighbourhoods. These areas also provide commercial activities like banking and shopping complexes and people visit them for patronage and to do transactions. 


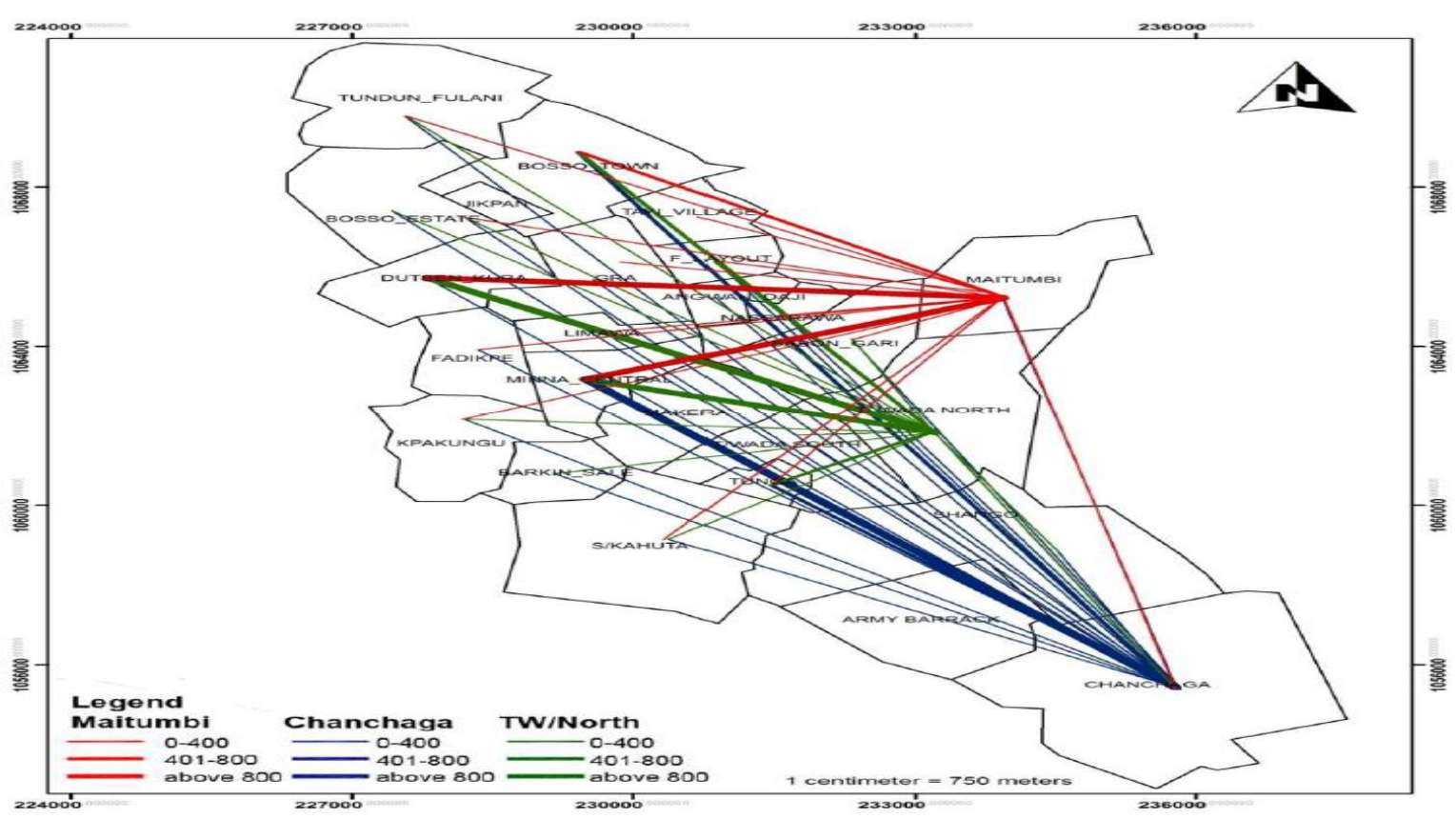

Figure 7: Zonal Trip Generation Patterns of Households in Cluster C

\section{Source: Author's Computer Generation (2017)}

Figure 7 reveals high level of interaction between Sauka Kahuta, Tunga, Dutsen Kura and Minna Central. Reasons for this high interface are because of the combine land use of residential, commercial and economic activities prevalent within these neighbourhoods. This invariably attracts trips among these areas. Barkin Sale and Bosso Town, Tunga and Dutsen Kura also attract high volume of trips as a result of the residential and educational land use activities which attracts residents, workers and students alike within and outside these neighbourhoods.

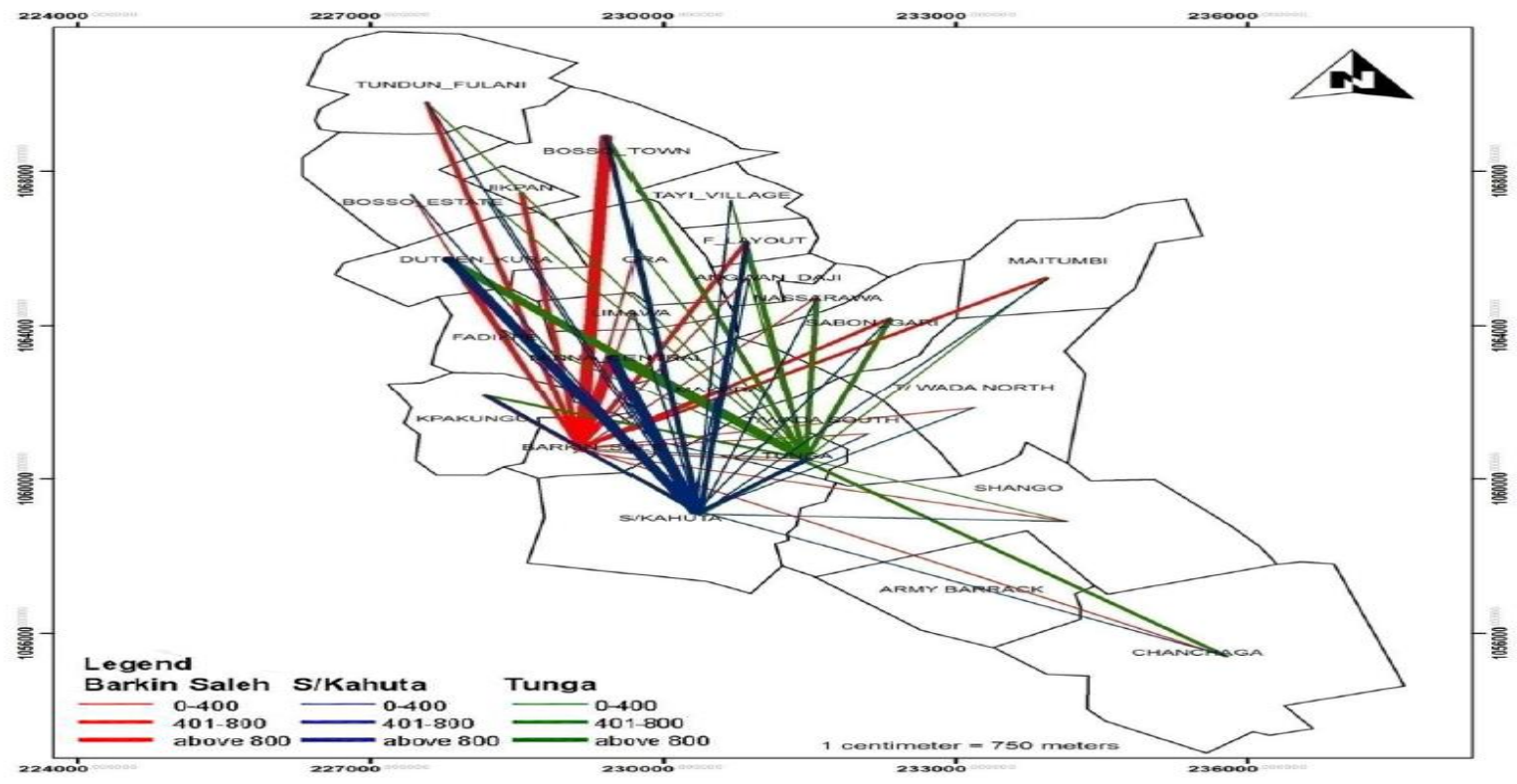

Figure 8: Zonal Trip Generation Pattern of Households in Cluster D

Source: Author's Computer Generation (2017) 
Table 3: Proportion Distribution of Trip Generated in Residential Densities

\begin{tabular}{|l|l|l|}
\hline Types of Residential Density & Total Trips Generated & $\mathbf{\%}$ \\
\hline Low & 2,052 & 16.9 \\
\hline Medium & 7,128 & 58.9 \\
\hline High & 2,911 & 24.2 \\
\hline Total & $\mathbf{1 2 , 0 9 1}$ & $\mathbf{1 0 0}$ \\
\hline
\end{tabular}

\section{Author's Data Analysis, 2017}

Table 3 Shows that among the three residential densities in the study area the Medium Residential Densities areas generated the highest volume of trips (7,128 trips) making up about 58.9\% of the total proportion of trips made, followed by the high densities neighbourhoods generating 2,911 trips weekly with $24.2 \%$ of total trips made. The least total trips generated among the residential densities was made by the Low Residential Densities Areas totalling about 2,052 trips weekly with $16.9 \%$.

Table 4: Population and Trip Generation of Residential Densities

\begin{tabular}{|l|l|l|}
\hline Residential Density & Total trips generated & Population \\
\hline Low & 2,052 & 27,644 \\
\hline Medium & 7,128 & 99,351 \\
\hline High & 2,911 & 49,758 \\
\hline Total & $\mathbf{1 2 , 0 9 1}$ & $\mathbf{1 7 6 , 7 5 3}$ \\
\hline
\end{tabular}

\section{Author's Data Analysis, 2017}

Table 4 Indicates total trips generated by residential densities in relation to their total population. This explains volumes of trips made by households were in relation to the population of each neighbourhood. The higher the population available the more the propensity to travel or make a trip across various activities centres in order to satisfy needs and desire of respective residents. Hence, the more diverse the socio-economic attributes and land use in each density the more the trips made to acquire and make use of utilities and services available in relation to satisfying diverse demand and deriving maximum satisfaction across the neighbourhoods.

\subsection{Analysis of Trip Purposes}

This section of the paper tries to analyse the various trip purposes made by the household in the City. The details are provided in Table 5.

Table 5: Proportion of No of Weekly Trips for Various Trip Purposes in Minna

\begin{tabular}{|l|l|l|l|l|l|l|l|l|l|}
\hline $\begin{array}{l}\text { Residential } \\
\text { Density }\end{array}$ & $\begin{array}{l}\text { Wo } \\
\text { rk }\end{array}$ & $\begin{array}{l}\text { Religi } \\
\text { ous }\end{array}$ & $\begin{array}{l}\text { Shoppi } \\
\text { ng }\end{array}$ & $\begin{array}{l}\text { Recreat } \\
\text { ion }\end{array}$ & $\begin{array}{l}\text { Soci } \\
\text { al }\end{array}$ & $\begin{array}{l}\text { Heal } \\
\text { th }\end{array}$ & $\begin{array}{l}\text { Scho } \\
\text { ol }\end{array}$ & $\begin{array}{l}\text { Busin } \\
\text { ess }\end{array}$ & $\begin{array}{l}\text { Total } \\
(\%)\end{array}$ \\
\hline Agwan daji & 24.6 & 14.7 & 17.6 & 6.3 & 4.9 & 2.1 & 8.4 & 21.4 & 100 \\
\hline Barkin sale & 17.1 & 15.8 & 13.5 & 6.3 & 11.4 & 5.9 & 13.7 & 16.3 & 100 \\
\hline Bosso & 16.5 & 13.5 & 13.3 & 10.1 & 12.7 & 8.4 & 13.2 & 12.3 & 100 \\
\hline Bosso estate & 18.9 & 11 & 11 & 10 & 13.9 & 8.2 & 17.4 & 9.6 & 100 \\
\hline Chanchaga & 23.8 & 11.9 & 10.1 & 10.4 & 13.3 & 6.5 & 15.3 & 8.7 & 100 \\
\hline Dutsen kura & 20.3 & 17.2 & 13.5 & 7.2 & 9.7 & 3.2 & 15.1 & 13.8 & 100 \\
\hline F-layout & 20.4 & 11.7 & 10.8 & 8.8 & 15 & 4.8 & 16.6 & 11.9 & 100 \\
\hline
\end{tabular}




\begin{tabular}{|l|l|l|l|l|l|l|l|l|l|}
\hline Jikpan & 19.5 & 11.1 & 7.5 & 6 & 6.4 & 5.3 & 17.1 & 27.1 & 100 \\
\hline Maitumbi & 20.8 & 15.4 & 10.5 & 8 & 11.3 & 5.7 & 13.9 & 14.4 & 100 \\
\hline Sauka kahuta & 22.1 & 18.3 & 15 & 6 & 13 & 1.4 & 16.5 & 7.7 & 100 \\
\hline $\begin{array}{l}\text { Tundu wada } \\
\text { north }\end{array}$ & 30.5 & 17 & 14.7 & 3.4 & 10.6 & 3.5 & 12.7 & 7.6 & 100 \\
\hline Tunga & 16.9 & 17.9 & 14.8 & 4.9 & 9.8 & 5.8 & 17 & 12.9 & 100 \\
\hline
\end{tabular}

Author's Data Analysis (2017)

From Table 5 shows that the proportion of movement of trips for various purposes across the study area indicates that respondents made a lot of trips for work related activities or toward work places right from Agwan daji to Tunga, followed by school, religious and business related trips respectively. While, the least proportion of trips in the study area was made for health purposes. This is not unexpected as Minna is basically a civil/public service city with presence of government ministries, schools (higher and lower institutions) and religious centres which are spatially located but more concentrated in some residential densities than others across the city.

Table 6: No of Trips, Cost and Distance Covered in Residential Densities

\begin{tabular}{|c|c|c|c|c|c|c|}
\hline $\begin{array}{l}\text { Residential } \\
\text { Density }\end{array}$ & $\begin{array}{l}\text { No of } \\
\text { Trip }\end{array}$ & $\%$ & $\begin{array}{l}\text { Cost of Trip in } \\
\text { Naira }\end{array}$ & $\%$ & Distance (Km) & $\%$ \\
\hline Low & $\begin{array}{l}2,052 \\
\text { (avg. } \\
12.7)\end{array}$ & $\begin{array}{l}16 . \\
9\end{array}$ & $\begin{array}{c}235,550 \\
(\text { avg. 1,472.2) }\end{array}$ & $\begin{array}{l}19 . \\
4\end{array}$ & $\begin{array}{c}4,434 \\
(\operatorname{avg} .27 .7)\end{array}$ & $\begin{array}{l}12 . \\
3\end{array}$ \\
\hline Medium & $\begin{array}{l}\text { 7,128 } \\
\text { (avg. } \\
15.1)\end{array}$ & $\begin{array}{l}58 . \\
9\end{array}$ & $\begin{array}{c}626,050 \\
\text { (avg. 1,332.0) }\end{array}$ & $\begin{array}{l}51 . \\
6\end{array}$ & $\begin{array}{c}17,079 \\
\text { (avg. 36.3) }\end{array}$ & $\begin{array}{l}47 . \\
8\end{array}$ \\
\hline High & $\begin{array}{l}2,911 \\
\text { (avg. } \\
11.4 \text { ) }\end{array}$ & $\begin{array}{l}24 . \\
2\end{array}$ & $\begin{array}{c}352,100 \\
\text { (avg. 1,375.4) }\end{array}$ & 29 & $\begin{array}{c}14,253 \\
(\text { avg. 58.9) }\end{array}$ & $\begin{array}{l}39 . \\
9\end{array}$ \\
\hline Total & $\begin{array}{l}\text { 12,091 } \\
\text { (avg. } \\
\text { 39.2) }\end{array}$ & 100 & $\begin{array}{c}1,213.70 \\
\text { (avg. 4,018) }\end{array}$ & 100 & $\begin{array}{c}35,766 \\
(\operatorname{avg.~123.)}\end{array}$ & 100 \\
\hline
\end{tabular}

Author's Data Analysis, 2017

Table 6 reveals that total number of trips made by respondents in Medium Residential Densities (7,128 trips) were much higher with a definite higher cost $(\mathrm{N} 626,050)$ incurred in making of such trips across various activities centres covered a total distance $4,434 \mathrm{~km}$. This is followed by the respondents living in High Residential Neighbourhoods with 2,911 trips, costing about N352,100 in relation to $14,253 \mathrm{~km}$ distances covered in actualising those trips. While, Low Residential Neighbourhoods make the least trips among the Residential densities with 2,052 trips costing respondents about N235,550 with a total of 4,434km distances covered across various trips attractions centres in the study area.

Table 7 Indicates that, significant difference exists in the total distances travelled for various purposes by respondents in the three residential densities. With a P-value of <.001 it shows the results is statistically significant and there are strong differences in the distance respondents have 
to covered in order to make a trip for various purposes. This may be as a result of spatial inbalances in the location of services needed and landuse activities across the residential densities. 
Table 7: ANOVA - Total Distance of Weekly Trips

\begin{tabular}{|l|l|r|l|c|c|}
\hline Cases & Sum of Squares & df & Mean Square & F & P \\
\hline Densities & 94727 & 2 & 47363.3 & 132.3 & $<.001$ \\
\hline Residual & 315782 & 885 & 358 & & \\
\hline
\end{tabular}

Author's Data Analysis (2017)

\section{Conclusions and Recommendations}

This study so far has revealed that Bosso Area generated the highest number of trips weekly with about $36.8 \%$ of total trips. While, Agwan daji generated the lowest trips with 142 weekly trips of about $1.2 \%$. Medium residential densities areas generated the highest trips with 7,128 weekly trips making up about $58.9 \%$. Also, work related activities attracted most number of trips. Analysis of variance reveals there are significant difference in distance covered in order to make a trip for various purposes with a p-value of $<0.001$. There is need to create spatial balance in the location of services needed and land use activities across the residential densities. It is advisable to provide a better mean of transportation to the city residents, improve road conditions and availability of ensure adequate free flow of traffic to reduce travel time which could mitigate the differences in trip making pattern in the study area.

From the findings so far, certain recommendations can be made for the city managers and planners. The first policy implication noticed from this study is that there is high level of spatial interaction among various land uses in the City. This has implication on the transport demand and supply in the city as well as traffic flow pattern in the city. Therefore, city transportation planners and managers need to ensure that adequate public transport services are provided for commuters particularly along the routes that link the major trip generation and attraction zones. Presently, the Minna does not have organised public transport system, it is high time the Municipal Government introduced effective and efficient public transport system along the major traffic corridors to ease urban mobility.

In order to diffuse the flow of traffic in the city, there should be a deliberate policy by the city planners to relocate some high trip attracting land uses to areas where there is less trip generation and attraction to reduce flow of traffic in those areas with high concentration of trip. Deliberate balancing of land use planning and relocation of land activities to less trip generation and attracting areas will diffuse city traffic and help in reducing congestion.

There is the need to focus attention on those routes that link the major trip generating and attracting zones by providing adequate traffic management and control measures in order to ensure free flow of movement.

\section{References}

[1] Ayeni, B. Concepts and Techniques in Urban Analysis, Croom Helm Ltd 1979.,. London.

[2] Clifton K.J. and C.L. Handy Qualitative methods in Travel Behaviour Research" Paper presented at the International Conference on Transport Survey Quality and Innovation, Kinger National Park, 2001 South.

[3] Boarnet, M., and Crane, R. The influence of land use on travel behaviour: specification and estimation strategies. Transportation Research Part A: Policy and Practice, 35(9), 2001, 823-845. 
[4] Dillman, D.A. Mail and Internet Surveys- the tailored design method, $2^{\text {nd }}$ ed. New York 2007,. https://www.researchgate.net.

[5] Fadare, O. and Salami, B.T., Telephone uses and the travel behaviour of residents in Osogbo, Nigeria; an empirical analysis. Journal of Transport Geography, 12, 2004, 159-164.

[6] Fadare S.O. and A.M. Hay "Housing Densities, Life style and travel behavior in Third World City: The example of Ibadan". Nigerian Journal of Economic and Social Studies. Vol. 32 No.2 1990 Pp 177-191.

[7] Hanson S. and P. Hanson The Travel Activity Pattern of Urban Residents: Dimensions and Relationships to Socio-Demographic Characteristics. Economic Geography. 1981, Pp 332-347.

[8] Harton, F. and J. Hultiquists, Urban households travel patterns: Definitions and relationship characteristics. East Lakes Geogr., 7, 1971, 27-48.

[9] Kansky, K. J., Travel patterns of urban residents. Transport. Sci., 1, 1967, 261-285.

[10] NBC. Socio-economic Survey. www.nigeriastat.gov.ng 2010.

[11] Okoko, E. E. Urban Transportation Planning and Modeling, Millennium Publishers, Akure, Nigeria, 2006, ISBN: 978-37465-5-3.

[12] Subbarao, S.S.V. and Krishna, R.K. Trip Chaining Behaviour in Developing Countries: A Study of Mumbai Metropolitan Region, India. European Transport/Transporti Europei, ISSTIES, Institute for the study of Transport within the European Economic Integration, Issue 53, 2013, pages 1-7.

[13] Solanke, M. Olayiwola. Socio-economic Determinants of Intra-Urban Trips Generation in Ogun State, Nigeria. Current Research Journal of Social Sciences 6 (1): 15-20, 2014 @ Maxwell scientific organization.

[14] Yago G. The Sociology of Transportation. Annual review of sociology. Vol. 9, 1983, 171-190. https://doi.org/10.1146/annurev.so.

*Corresponding author.

E-mail address: ojekun@ yahoo.com 